\title{
Protective Effects of Fucoidan against UVB-Induced Oxidative Stress in Human Skin Fibroblasts
}

\author{
Mi Jung Ku, Myeong Sook Lee, Hee Jung Moon and Yong Hwan Lee* \\ Institute of Natural Products for Health Promotion and Department of Preventive Medicine, College of Medicine, Kosin University, \\ 34 Amnam-Dong, Suh-Gu, Busan, 602-702, Korea
}

Received November 5, 2009 /Accepted November 30, 2009

\begin{abstract}
Ultraviolet-B (UVB) radiation induces the formation of reactive oxygen species (ROS) and depletes stores of cellular antioxidants. Fucoidan, polysaccharides containing L-fucose and sulfate ester groups, are constituents of brown algae. In this study, the protective effects of fucoidan on UVB-induced oxidative stress in cultured human skin fibroblast HS68 cells were assessed. Pretreatment with fucoidan significantly reduced malondialdehyde (MDA) content in a dose-dependent manner. With fucoidan pretreatment at a dose of $100 \mu \mathrm{g} / \mathrm{ml}$, the level of intracellular glutathione was increased by $21.5 \%$, compared to UVB irradiation alone. Fucoidan significantly reduced UVB-induced ROS generation by $40.1 \%$ and $68.4 \%$ at 10 and $100 \mu \mathrm{g} / \mathrm{ml}$, respectively, compared to UVB irradiation alone. The positive staining rates of senescence-associated $\beta$-galactosidase were reduced by $23.1 \%$ and $16.4 \%$ with 10 and $100 \mu \mathrm{g} / \mathrm{ml}$ of fucoidan, compared to UVB irradiation alone. Fucoidan may exert a photoprotective effect against UVB radiation-induced oxidative stress.
\end{abstract}

Key words : Fucoidan, ultraviolet B, antioxidation

\section{Introduction}

Sunlight contains non-photosynthetic wavelengths, including shorter wavelengths such as ultraviolet-B (UVB, 280-320 nm) radiation. The depletion of the stratospheric ozone levels results in an increase in the amount of solar UVB radiation reaching the earth's surface. UVB is also known to be damaging to living organisms, as cellular components such as proteins and nucleic acids absorb this energy-rich radiation [5].

The skin is constantly and directly exposed to the environment. Thus, the exposure of the human skin to UVB radiation results in the depletion of cutaneous antioxidants, including superoxide dismutase (SOD), catalase (CAT), and glutathione (GSH), the deregulation of gene expression and, ultimately, to the development of skin disease [6]. UVB radiation generates reactive oxygen species (ROS), which results in the creation of cellular oxidative stress conditions. ROS and free radicals are highly reactive oxygen metabolites, and include the superoxide radical $\left(\mathrm{O}_{2}^{-}\right)$, hydrogen peroxide $\left(\mathrm{H}_{2} \mathrm{O}_{2}\right)$, and the hydroxyl radical $\left(\mathrm{OH}^{-}\right)$. These can induce the peroxidation of cell membrane lipids, in addition to DNA mutation and protein damage [13]. DNA is under con-

*Corresponding author

Tel : +82-51-990-6459, Fax : +82-51-246-7201

E-mail : yhlee@kosin.ac.kr stant attack from these reactive species. The interaction of ROS with DNA can cause a multiplicity of products of varying structures and with differing biological impacts.

There is also data to indicate the ROS-induced lipid peroxidation of cell membranes may represent another different mechanism in the evolution of cell injury. The amount of radicals that actually reach the DNA and cell membranes, thus producing damage, is limited by the activity of cellular antioxidants [2]. Under normal conditions, ROS and free radicals are cleared from the cell via both the activities of SOD, CAT, or glutathione peroxidase (GPx), which collectively function as an enzymatic defense system, and via the scavenging of non-enzymatic antioxidants, including vitamins and flavonoids [13].

In recent years, the development of compounds isolated from natural products which evidence antioxidative activities has become the focus of a great deal of attention. Brown seaweeds have long been a staple of both the Korean and Japanese diets, and have also been documented as in the annals of traditional Chinese medicine for more than 1000 years [15]. Extracts prepared from seaweeds have received specific attention as the result of their potent pharmacological activities, including immuno-stimulation, antitumor, and antioxidant activities [12]. Fucoidan, polysaccharides containing L-fucose and sulfate ester groups, are constituents of brown algae. Within the past decade, fucoi- 
dans have been extensively studied, owing to their numerous biological activities, including anti-coagulant, anti-thrombotic, anti-inflammatory, anti-tumor, and anti-viral effects [4].

The principal objective of this study was to assess the antioxidative effects of fucoidan through UVB-induced malondialdehyde (MDA), GSH, ROS, and senescence associated $\beta$-galactosidase (SA $\beta$-gal) assays, using the human skin fibroblast HS68 cell line.

\section{Materials and Methods}

\section{Chemicals}

Fucoidan, 2',7'-dichlorodihydrofluorescein diacetate (DCFDA) and 1,1,3,3-tetraethoxypropane (TMP) were purchased from Sigma (St. Louis, MO). The glutathione assay kit was purchased from Bioassaysys (Hayward, CA). The culture medium (Dulbecco's modified of Eagle's medium, DMEM), fetal bovine serum (FBS) and penicillin- streptomycin were obtained from Gibco (Grand Island, NY). All other purchased chemicals were analytical-grade or reagent-grade.

\section{Cell culture}

The normal human newborn foreskin fibroblasts cell lines, HS68 cells (ATCC CRL 1635), were obtained from the American Type Culture Collection (Rockville, MD). The complete culture medium for the HS68 cells was DMEM containing $10 \%$ fetal bovine serum, and $1 \%$ penicillinstreptomycin. The cells were maintained at $37^{\circ} \mathrm{C}$ in a humid incubator with a $5 \% \mathrm{CO}_{2}$ atmosphere.

\section{Ultraviolet irradiation and fucoidan treatment}

For treatment, the HS68 cells were maintained in culture media without FBS overnight and followed by $24 \mathrm{hr}$ of fucoidan pretreatment. The cells were then rinsed twice in phosphate-buffered saline (PBS), and all UVB irradiations were conducted under a thin layer of PBS. Non-irradiated cells were similarly treated in parallel, and were maintained at room temperature. UVB irradiation was conducted using a Philips TL 20W/12RS fluorescent sun lamp (Amsterdam, Holland), which provided radiation in a range of 285-350 $\mathrm{nm}$ with an emission peak at 310-315 nm. The cells were then exposed to a $100 \mathrm{~mJ} / \mathrm{cm}^{2}$ dose of UVB light. Following UVB irradiation, the PBS was removed, serum-free medium with fucoidan was applied and the cells were subsequently incubated for $24 \mathrm{hr}$ at $37^{\circ} \mathrm{C}$.
The following parameters were utilized to monitor of the effects of fucoidan on UVB-irradiated human fibroblast cells: MDA levels, GSH levels, ROS generation, and SA $\beta$-gal.

\section{Measurement of MDA levels}

The concentration of MDA $(\mathrm{nmol} / \mathrm{ml})$ was determined via a modified version of the method developed by Ohkawa et al. [18]. After the application of UVB irradiation, the HS68 cells were cultured for $24 \mathrm{hr}$ in $100 \mathrm{~mm}$ tissue culture dishes. The cells were mixed with thiobarbituric acid (TBA) reagent consisting of $46 \mathrm{mM}$ TBA and $920 \mathrm{mM}$ trichloroacetic acid (TCA) in $20 \%$ acetic acid ( $\mathrm{pH} 3.5$ ). The reaction mixtures were then boiled for $30 \mathrm{~min}$ at $95^{\circ} \mathrm{C}$. After collecting the supernatants of each group, the absorbance was spectrophotometrically assessed at $532 \mathrm{~nm}$ and compared with a standard curve prepared from different concentrations of 1,1,3,3tetramethoxypropane.

\section{Measurement of GSH levels}

After UVB irradiation, the HS68 cells were cultured for $24 \mathrm{hr}$ in $100 \mathrm{~mm}$ tissue culture dishes. The cells were washed twice with PBS, and lysed in $50 \mathrm{mM}$ phosphate buffer $(\mathrm{pH}$ 7.0) and $1 \mathrm{mM}$ EDTA. The supernatants of each group were then collected, and the GSH levels were determined using a glutathione assay kit. The supernatant of each group was mixed with $120 \mu \mathrm{l}$ of reagent A. After vortexing, $200 \mu \mathrm{l}$ of this mixed solution was mixed with $100 \mu \mathrm{l}$ of reagent $\mathrm{B}$. Following 20-25 min of incubation at $25^{\circ} \mathrm{C}$, the absorbance was measured at $412 \mathrm{~nm}$.

\section{Measurement of intracellular ROS generation}

The oxidation-sensitive fluorescent probe, DCF-DA, was used for the analysis of intracellular ROS generation, as previously described [1]. The polar, pre-fluorescent DCF-DA undergoes deacetylation by cytosolic esterases to form DCFDA, which reacts with ROS and gives rise to fluorescein. In order to measure the levels of ROS production levels, HS68 cells were exposed to UVB irradiation after $24 \mathrm{hr}$ of fucoidan pretreatment. The cells were washed twice with phosphate-buffered saline (PBS) and incubated for $30 \mathrm{~min}$ with $20 \mu \mathrm{M}$ DCF-DA in DMEM at $37^{\circ} \mathrm{C}$.

\section{SA $\beta$-gal staining}

SA $\beta$-gal staining was conducted in accordance with the methods described by Yang and $\mathrm{Hu}$ [19]. In brief, the cells, which were pretreated with fucoidan and UVB irradiation, 
were washed twice in PBS and fixed for $5 \mathrm{~min}$ in 3\% formaldehyde. They were then washed and incubated at $37^{\circ} \mathrm{C}$ with fresh SA $\beta$-gal stain solution $(1 \mathrm{mg} / \mathrm{ml}$ of $X-G a l$, $5 \mathrm{mM}$ of pottssium ferricianide, $5 \mathrm{mM}$ of potassium ferrocyanide, $150 \mathrm{mM}$ of $\mathrm{NaCl}, 2 \mathrm{mM}$ of $\mathrm{MgCl}_{2}$ in PBS at $\mathrm{pH}$ 6.0). Staining became apparent in 12-16 hr. The cells were counted at $\times 200$ magnification.

\section{Statistical analysis}

All experiments were conducted three times. The data were expressed as mean \pm standard deviation (SD). The results were evaluated via unpaired t-test for individual comparisons, all of which were conducted with the SPSS software package. The statistical level of significance was set at $\mathrm{p}<0.05$.

\section{Results}

\section{Effect of fucoidan on the lipid peroxidation}

MDA is the principal product of lipid peroxidation, and the MDA content was utilized as an indicator to estimate the effect of fucoidan on lipid peroxidation. The cells were pretreated for $24 \mathrm{hr}$ with various treatment concentrations of fucoidan $(1,10$ or $100 \mu \mathrm{g} / \mathrm{ml})$ followed by UVB irradiation $\left(100 \mathrm{~mJ} / \mathrm{cm}^{2}\right)$. The cells were further incubated for an additional $24 \mathrm{hr}$. The MDA content was increased by 32.0\% with UVB irradiation as compared to the UVB non-irradiated group (Fig. 1). However, fucoidan significantly reduced MDA content by $20.8 \%, 24.6 \%$, and $31.4 \%$ at 1,10 , and $100 \mu \mathrm{g} / \mathrm{ml}$, respectively, compared to UVB irradiation alone $(p<0.05)$.

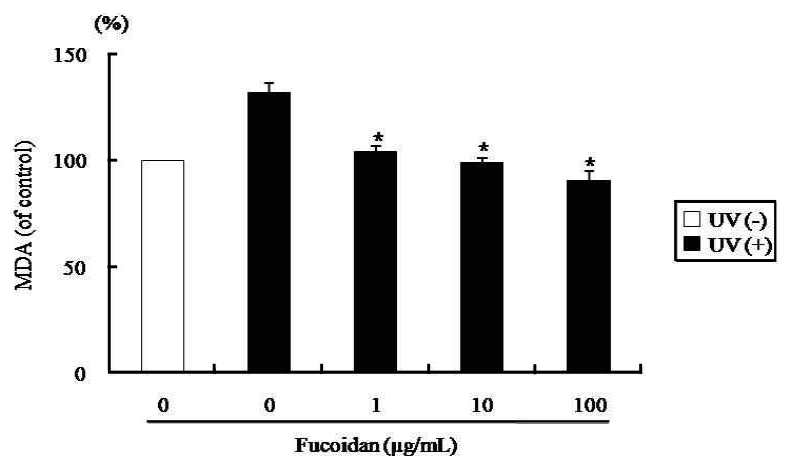

Fig. 1. Effect of fucoidan on MDA production induced by UVB in human skin fibroblasts. The cells were pretreated with fucoidan $(0,1,10$, and $100 \mu \mathrm{g} / \mathrm{ml})$ prior to UVB irradiation $\left(100 \mathrm{~mJ} / \mathrm{cm}^{2}\right)$, and harvested after $24 \mathrm{hr}$ later. MDA levels were measured using the thiobarbituric acid method, as described in materials and methods. Each bar represents the mean \pm SD. ${ }^{*} p<0.05$ versus UVB irradiation alone.

\section{Effect of fucoidan on intracellular GSH levels}

The intracellular GSH level was reduced to $16.7 \%$ by UVB irradiation $\left(100 \mathrm{~mJ} / \mathrm{cm}^{2}\right)$ in HS68 cells, as compared to the UVB non-irradiated group (Fig. 2). However, with fucoidan pretreatment at a dose of $100 \mu \mathrm{g} / \mathrm{ml}$, the levels of intracellular GSH was increased by $21.5 \%$ as compared to the UVB irradiation only group $(\mathrm{p}<0.05)$.

\section{Effect of fucoidan on ROS generation}

ROS production was evaluated via the DCF-DA method. UVB induced an increase in intracellular ROS as compared to the UVB-non-irradiated group (Fig. 3). Fucoidan significantly reduced UVB-induced ROS generation by $40.1 \%$ and $68.4 \%$ at 10 and $100 \mu \mathrm{g} / \mathrm{ml}$, respectively, compared to

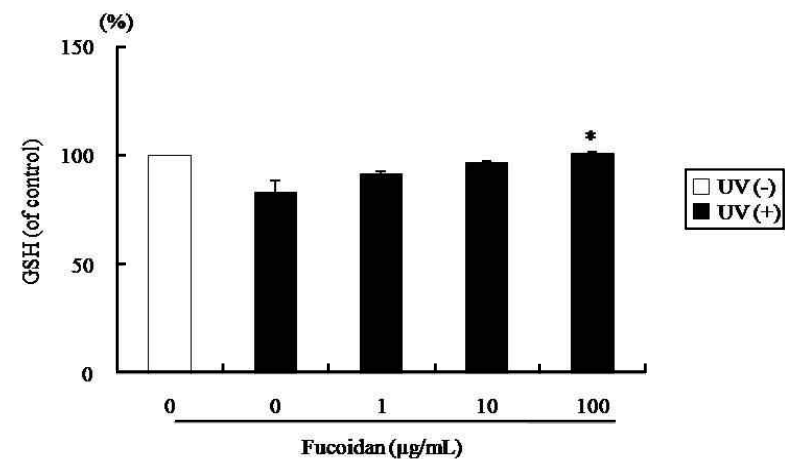

Fig. 2. Effect of fucoidan on intracellular GSH level induced by UVB in human skin fibroblasts. The cells were pretreated with fucoidan $(0,1,10$, and $100 \mu \mathrm{g} / \mathrm{ml})$ prior to UVB irradiation $\left(100 \mathrm{~mJ} / \mathrm{cm}^{2}\right)$, and harvested after $24 \mathrm{hr}$ later. The GSH levels were measured using the 5,5-dithiobit (2-nitrobenzoic acid) (DTNB), as described in materials and methods. Each bar represents the mean \pm SD. ${ }^{*} p<0.05$ versus UVB irradiation alone.

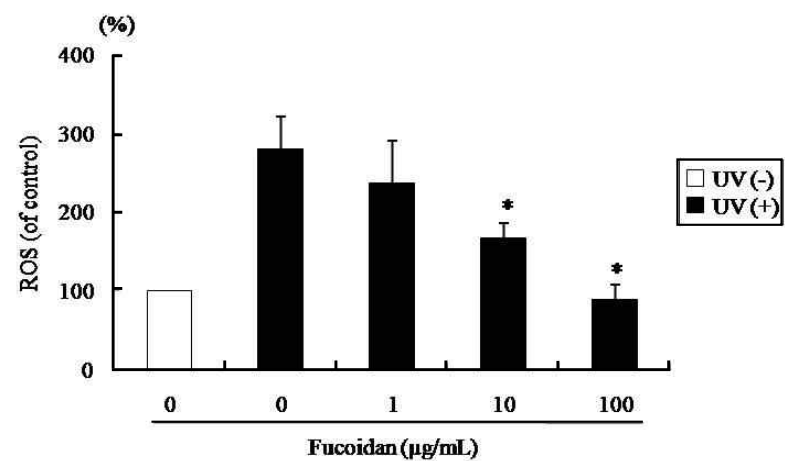

Fig. 3. Effect of fucoidan on ROS generation induced by UVB in human skin fibroblasts. The cells were pretreated with fucoidan $(0,1,10$, and $100 \mu \mathrm{g} / \mathrm{ml})$ prior to UVB irradiation $\left(100 \mathrm{~mJ} / \mathrm{cm}^{2}\right)$. Followed by incubation for $1 \mathrm{hr}$, the production of ROS was determined by DCF-DA method. ${ }^{*} p<0.05$ versus UVB irradiation alone. 


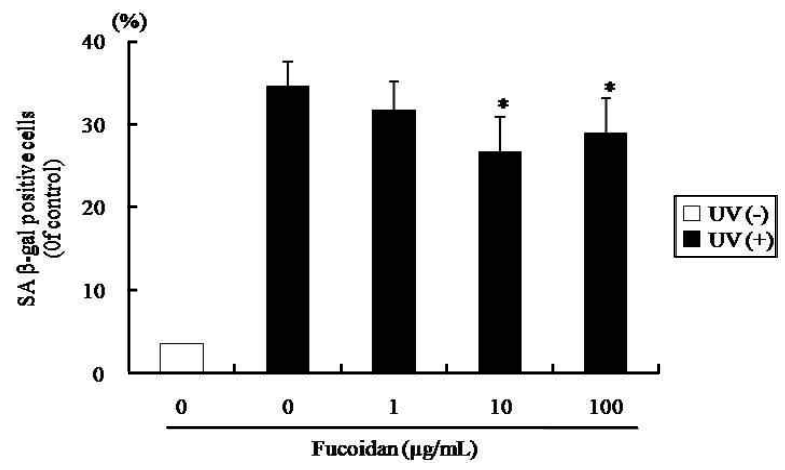

Fig. 4. Effect of fucoidan on $\beta$-galatosidase activity in human skin fibroblasts. The cells were pretreated with fucoidan $(0,1,10$, and $100 \mu \mathrm{g} / \mathrm{ml})$ prior to UVB irradiation $(100$ $\left.\mathrm{mJ} / \mathrm{cm}^{2}\right)$, and were stained as described in materials and methods. In all cases a minimum of 400 cells were counted for each data point. Each bar represents the mean \pm SD. ${ }^{*} p<0.05$ versus UVB irradiation alone.

UVB irradiation alone $(\mathrm{p}<0.05)$.

\section{Effect of fucoidan on SA $\beta$-gal activity}

To determine cell senescence as the result of oxidative stress induced by UVB irradiation $\left(100 \mathrm{~mJ} / \mathrm{cm}^{2}\right)$ in the HS68 cells, the SA $\beta$-gal activity was assessed. The positive staining rates of SA $\beta$-gal were reduced by $23.1 \%$ and $16.4 \%$ at 10 and $100 \mu \mathrm{g} / \mathrm{ml}$ of fucoidan, respectively, compared to UVB irradiation alone $(\mathrm{p}<0.05$, Fig. 4$)$

\section{Discussion}

UV radiation penetrates readily into dermal tissue and has been confidently and consistently implicated in the aging of skin. Therefore, human dermal skin fibroblasts are considered to be a useful model for investigation of the effects of antioxidants on UV-induced skin photoaging [17]. UVB interacts with cellular chromophores and photosensitizers, resulting in the ROS generation, DNA damage, and the activation of cytoplasmic signal transduction pathways, which are associated with growth, differentiation, replicative senescence, and the degradation of connective tissue [9]. According to many researchers, UVB induces a dramatic dose-dependent reduction in intracellular GSH, intramembrane vitamin $\mathrm{E}$, and membrane fluidity, in addition to an increase in MDA levels $[3,16]$.

In this study, the MDA contents of cells, employed herein as a marker of lipid peroxidation [11], was elevated as the result of UVB irradiation. With fucoidan pretreatment, lipid peroxidation was inhibited during UVB irradiation. MDA, a by-product of lipid peroxidation, is considered a strongly cytotoxic second messenger which can diffuse within or even escape from the cell, and attack targets distant from the production site. Lipid peroxidation is a complex radical chain reaction, by which unsaturated membrane lipids are oxidized. This process results directly in membrane modifications provoked by reactive lipid peroxidation products such as hydroperosides. Lipid peroxidation has been recognized as a critical mechanism in cell injuries occurring during oxidative stress [2]. Ho et al. [10] previously reported that the MDA level at $150 \mathrm{~mJ} / \mathrm{cm}^{2}$ of UVB irradiation was approximately 2.2-fold that of the non-irradiated cells. This result is generally consistent with ours, although the experimental conditions differed.

In this study, fucoidan pretreatment was demonstrated to attenuate DCF fluorescence. The DCF fluorescence is representative of intracellular activity, and thus an increase in fluorescence is suggestive of intracellular oxidative stress. The GSH content was reduced significantly in the UVB-irradiated cells, whereas fucoidan also inhibited the UVB-induced decline in GSH content in the skin fibroblasts. The results of the current study suggest that the initial depletion of GSH by UVB induces an increase in ROS production. As GSH is the principal antioxidant system in the cells, the depletion of GSH may profoundly affect cell death as the result of ROS accumulation in UVB-irradiated cells [14]. UVB radiation is a potent inducer of apoptosis. UVB-mediated nuclear DNA damage has been identified as the primary molecular trigger for the induction of apoptosis. Recently, UVB-generated ROS has been demonstrated to perform an additional function in the execution of apoptotic cell death [20]. In culture and in vivo biopsy, SA $\beta$-gal was measured in a variety of cells and tissues in order to assess the onset of cell senescence [19]. Eukaryotic $\beta$-galactosidase is a hydrolase localized in the lysosome, which cleaves $\beta$-D-galactose residues in $\beta$-D-galactosides. In 1995, one report suggested that the senescent cells express a specific type of the enzyme $\beta$ galactosidase referred to as SA $\beta$-gal which has an optimal $\mathrm{pH}$ at 6.0 [7]. Thus far, the SA $\beta$-gal assay has become one of the most commonly used markers of cell aging in vitro, especially as the result of factors such as sublethal oxidative stress [8]. In this study, fucoidan was shown to reduce SA $\beta$-gal activity, and we confirmed that it performs an important function in the retardation of senescent fibroblast accumulation in human skin.

These results suggest that fucoidan may exert a photo- 
protective effect against UVB radiation-induced oxidative stress.

\section{References}

1. Brandt, R. and A. S. Keston. 1965. Synthesis of diacetyldichlorofluorescin: A stable reagent for fluorometric analysis. Anal. Biochem 11, 6-9.

2. Campo, G. M., A. Avenoso, S. Campo, A. D'Ascola, A. M. Ferlazzo, and A. Calatroni. 2004. Reduction of DNA fragmentation and hydroxyl radical production by hyaluronic acid and chondroitin-4-sulphate in iron plus ascorbate-induced oxidative stress in fibroblast cultures. Free Radic. Res. 38, 601-611.

3. Carini, M., G. Aldini, E. Bombardelli, P. Morazzoni, and R. Maffei Facino. 2000. UVB-induced hemolysis of rat erythrocytes: protective effect of procyanidins from grape seeds. Life Sci. 67, 1799-1814.

4. Chizhov, A. O., A. Dell, H. R. Morris, S. M. Haslam, R. A. McDowell, A. S. Shashkov, N. E. Nifant'ev, E. A. Khatuntseva, and A. I. Usov. 1999. A study of fucoidan from the brown seaweed Chorda filum. Carbohydr. Res. 320, 108-119.

5. Costa, H., S. M. Gallego, and M. L. Tomaro. 2002. Effect of UV-B radiation on antioxidant defense system in sunflower cotyledons. Plant Sci. 162, 939-945.

6. Darr, D. and I. Fridovich. 1994. Free radicals in cutaneous biology. J. Invest. Dermatol. 102, 671-675.

7. Dimri, G. P., X. Lee, G. Basile, M. Acosta, G. Scott, C. Roskelly, E. E. Medrano, M. Linskensi, I. Rubeljii, O. Pereira-Smith, M. Peacocke, and J. Campisi. 1995. A biomarker that identifies senescent human cells in culture and aging skin in vivo. Proc. Natl. Acad Sci. 92, 9363-9367.

8. Dumont, P., M. Burton, Q. M. Chen, E. S. Gonos, C. Frippiat, J. B. Mazarati, F. Eliaers, J. Remacle, and O. Toussaint. 2000. Induction of replicative senescence biomarkers by sublethal oxidative stresses in normal human fibroblast. Free Radic. Biol. Med 28, 361-373.

9. Helenius, M., L. Makelainen, and A. Salminen. 1999. Attenuation of NF-kappaB signaling response to UVB light during cellular senescence. Exp. Cell Res. 248, 194-202.

10. Ho, J. N., Y. H. Lee, J. S. Park, W. J. Jun, H. K. Kim, B.
S. Hong, D. H. Shin, and H. Y. Cho. 2005. Protective effects of aucubin isolated from Eucommia ulmoides against UVB-induced oxidative stress in human skin fibroblasts. Biol. Pharm Bull. 28, 1244-1248.

11. Jones, S. A., F. McArdle, C. I. Jack, and M. J. Jackson. 1999. Effect of antioxidant supplementation on the adaptive response of human skin fibroblasts to UV-induced oxidative stress. Redox Rep. 4, 291-299.

12. Kang, K. A., H. D. Bu, D. S. Park, G. M. Go, Y. Jee, T. Shin, and J. W. Hyun. 2005. Antioxidant activity of ethanol extract of Callophyllis Japonica. Phytother. Res. 19, 506-510.

13. Lee, B. C., S. Y. Lee, H. J. Lee, G. S. Sim, J. H. Kim, J. H. Kim, Y. H. Cho, D. H. Lee, H. B. Pyo, T. B. Choe, D. C. Moon, Y. P. Yun, and J. T. Hong. 2007. Anti-oxidative and photo-protective effects of coumarins isolated from Fraxinus Chinensis. Arch Pharm. Res. 30, 1293-1301

14. Lee, C. S., S. Y. Park, H. H. Ko, and E. S. Han. 2004. Effect of change in cellular GSH levels on mitochondrial damage and cell viability loss due to mitomycin c in small cell lung cancer cells. Biochem Pharmacol. 68, 1857-1867.

15. McLellan, D. S. and K. M. Jurd. 1992. Anticoagulants from marine algae. Blood Coagul. Fibrinolysis. 3, 69-77.

16. O'Connor, I. and N. O'Brien. 1998. Modulation of UVA light-induced oxidative stress by beta-carotene, lutein and astaxanthin in cultured fibroblasts. J. Dermatol. Sci. 16, 226-230.

17. Offord, E. A., J. C. Gautier, O. Avanti, C. Scaletta, F. Runge, K. Krämer, and L. A. Applegate. 2002. Photoprotective potential of lycopene, beta-carotene, vitamin $\mathrm{E}$, vitamin $\mathrm{C}$ and carnosic acid in UVA-irradiated human skin fibroblasts. Free Radic. Biol. Med 32, 1293-303.

18. Ohkawa, H., N. Ohishi, and K. Yagi. 1979. Assay for lipid peroxides in animal tissues by thiobarbituric acid reaction. Anal. Biochem 95, 351-358.

19. Yang, N. C. and M. L. Hu. 2004. A fluorimetric method using fluorescein di- $\beta-D$-galactopyranoside for quantifying the senescence-associated $\beta$-galactosidase activity in human foreskin fibroblast Hs68 cells. Anal. Biochem 325, 337-343.

20. Zeise, E., M. Weichenthal, T. Schwarz, and D. Kulms. 1004. Resistance of human melanoma cells against the death ligand TRAIL is reversed by ultraviolet-B radiation via downregulation of FLIP. J. Invest. Dermatol. 123, 746-754. 


\section{초록 : 자외선에 의해 유도된 인간 피부 섬유아세포의 산화 스트레스에 대한 후코이단의 보호효과}

구미정 · 이명숙· 문희정 · 이용환ㅊ

(고신대학교 의과대학 건강증진천연물연구소 및 예방의학교실)

자외선 B는 반응성 산소종(reactive oxygen species, ROS)의 발생을 유도하고 세포내 항산화 물질의 저장을 방해한다. 후코이단은 L-fucose와 황 에스터기를 포함하는 다당류로서 갈조류의 주요 성분으로 알려져 있다. 본 연구에서는 인간 피부 섬유아세포인 HS68세포에 자외선을 조사하여 산화 스트레스를 유도한 후 후코이단의 보호효 과를 확인하고자 하였다. 후코이단의 전처치로 malondialdehyde (MDA)의 양이 용량-의존적으로 감소하였고, 세포 내 glutathiopne도 후코이단 $100 \mu \mathrm{g} / \mathrm{ml}$ 을 투여하였을 때 후코이단을 투여하지 않고 자외선만 조사한 군에 비하여 $21.5 \%$ 감소하였다. 후코이단을 $10,100 \mu \mathrm{g} / \mathrm{ml}$ 의 용량으로 투여하였을 경우 자외선 B에 의한 ROS 생성이 자외선만 조사하였을 때 보다 각각 $40.1 \%$ 와 $68.4 \%$ 로 유의하게 감소하였다. 세포노화와 관련된 $\beta$-galactosidase의 양성 염색률 은 후코이단을 $10,100 \mu \mathrm{g} / \mathrm{ml}$ 투여하였을 경우 자외선만 조사하였을 때보다 각각 $23.1 \%, 16.4 \%$ 감소하였다. 이러한 결과로 미루어 후코이단은 자외선에 의한 산화 스트레스에 대하여 광보호 효과가 있는 것으로 생각된다. 